Nielsen, B. L. 1980: The uranium potential of Greenland - a geological analysis of favourability. In Uranium evaluation and mining techniques. (Proc. Symposium Buenos Aires, 1-4 Oct. 1979). Vienna: Int. Atomic Energy Agency.

\title{
Uranium districts in South Greenland
}

\author{
Ashlyn Armour-Brown, Tapani Tukiainen and Bjarne Wallin
}

From the preliminary evaluation of the reconnaissance exploration results in 1979, two areas were outlined as having some potential for uranium mineralisation (Armour-Brown $e t$ al., 1979). Further evaluation of the data extended the northern of these two areas to include the area which lies just south of the Igaliko Fjord (Vatnaverfi area, fig. 18). In addition the northern part of the Igaliko nepheline syenite complex, the Motzfeldt centre, was shown to be more interesting as a result of the evaluation of gamma-spectrometer results and the identification of uraniferous pyrochlore from some of the rock samples. Some smaller anomalous areas in the Kobberminebugt area north-east of Nunarssuit, and Kap Farvel region, particularly in areas of metasedimentary rocks, were identified by reconnaissance geochemistry.

The 1980 field season was devoted mostly to gathering data to assist in the interpretation of the reconnaissance results. During the course of this work extensive areas with high radioactivity were found over the eastern and northern parts of the Motzfeldt centre. Six pitchblende occurrences and numerous radioactive occurrences were found in the 'Granite Zone' (fig. 18). Uraninite was also found in the Tasermiut area (Nielsen \& Tukiainen, this report).

Gamma-spectrometer results (thorium, uranium) of the aerial survey covering the more interesting parts of the field area were compiled and plotted before the field season and were used in the field work. During this field season some $1500 \mathrm{~km}$ of gamma-spectrometer flight routes were measured. This allowed the completion of the reconnaissance flight routes at a more or less even density over the whole field area, as well as some closer spaced lines in some smaller areas of interest, in order to test the usefulness of the method in follow-up work in the different terrains.

\section{Motzfeldt centre}

Based on the results of the 1979 reconnaissance a more detailed airborne gamma-spectrometer survey was made and geological mapping of a reconnaissance nature was carried out over the Motzfeldt centre.

The airborne survey revealed extensive areas, as well as numerous minor localities, of highly radioactive rocks which are situated within the syenite units SM 1 and SM 2 in the northern part of the centre and within the 'East Motzfeldt Syenite' (Emeleus \& Harry, 


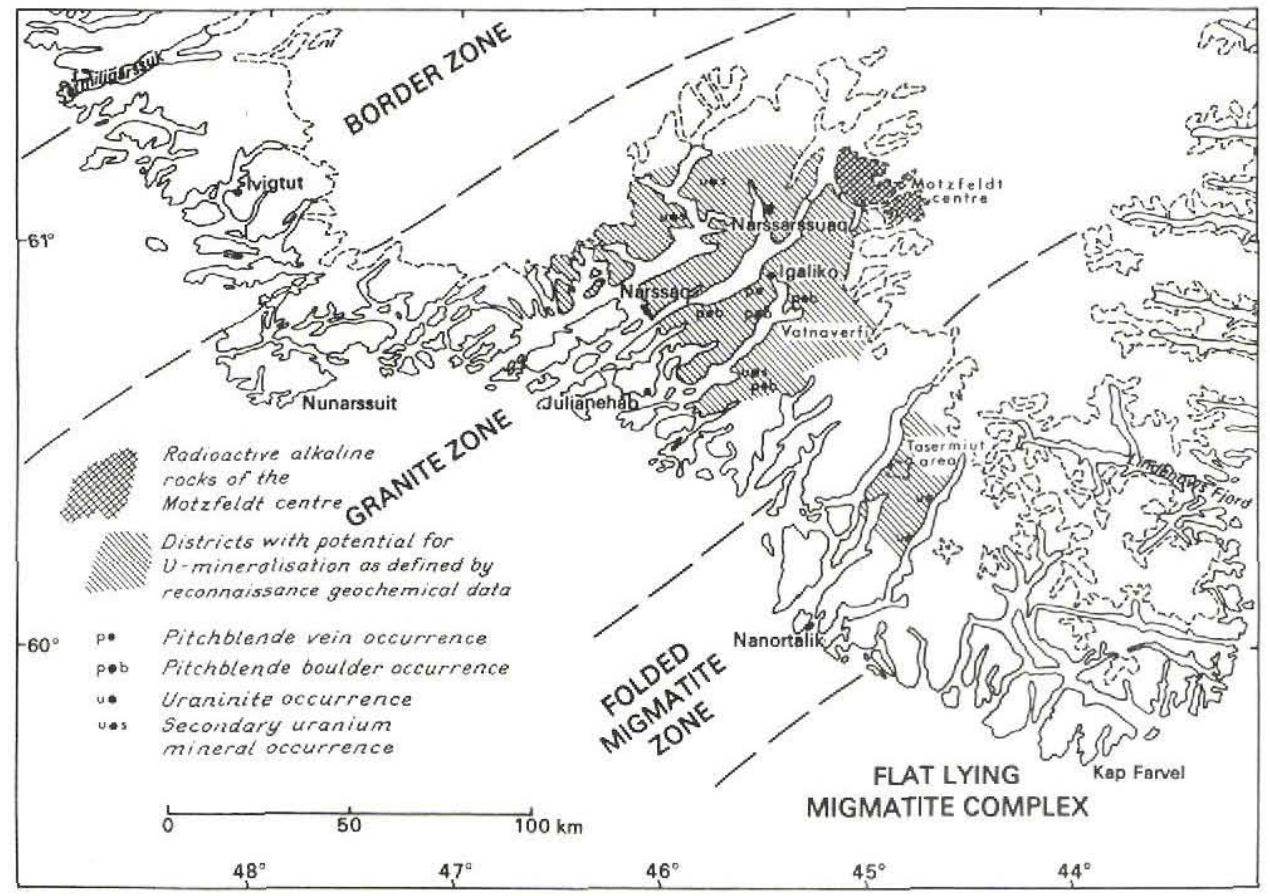

Fig. 18. Areas with potential for economic uranium mineralisation and some uranium mineral occurrences. The zones indicated are divisions of the Ketilidian mobile belt as defined by Allaart (1976).

1970). Interesting anomalies were also recorded east of the known syenite units and these were found to lie within a fairly large unmapped syenite body.

A preliminary evaluation of the gamma-spectrometer results indicates that thorium is the main contributor to the high radioactivity. There are also, however, quite extensive areas where uranium becomes an important component, and U/Th ratios greater than 1 were recorded.

The 'East Motzfeldt Syenite' is a complex unit of various alkaline rocks. Macroscopiscally the following rock types can be distinguished: (1) fine-grained syenite, (2) medium-grained 'granite', (3) medium- to coarse-grained nepheline syenite, (4) xenolithic, mesocratic to melanocratic porphyritic syenite, (5) mafic rocks, often agglomeratic with a matrix of carbonatite, and (6) various pegmatites. Scattered minor rafts of quartzite were found in the syenite but the supracrustal units shown on the map by Emeleus \& Harry (1970) do not exist. The rocks are cut by later ENE-striking felsic dykes.

The rocks are generally accompanied by a varying degree of alteration with iron oxides, and also manganese oxide, especially in the more fractured rocks. Fluorite is ubiquitous, occurring as disseminated grains, or enriched in veinlets in pegmatite and breccia together with quartz, feldspar and haematite. Some of the rocks frequently contain sulphides, mainly pyrite and some galena. Because wide parts of the area are insufficiently exposed the 
detailed relationships between the different rock types could not be ascertained. Later ENE fractures and possibly also faults in other directions cut all the rock units.

The rocks with the highest radioactivity are the fine grained syenite and medium-grained 'granite'. High radioactivity was also found in the altered medium- to coarse-grained nepheline syenite and basic rocks. Macroscopic radioactive minerals have not been identified. The general distribution of the rock units indicates that the fine-grained syenite and medium-grained 'granite' are extensive laccolithic sheets extending far into the granite basement and including rafts of it.

The northern part of the Motzfeldt centre is made up of: (1) a sequence of altered syenite, (2) homogeneous, fresh, medium grained nepheline syenite, and (3) sandstone and basalt. The syenite units intrude the series of sandstone and basalt. The area is cut by numerous felsic dykes, most of which belong to a later ENE-directed set of dykes.

The sequence of altered syenite ranges from medium-grained to coarse-grained pegmatitic syenite with a variable amount of alteration which is due to the introduction of iron and manganese oxides and alkaline volatiles (e.g. formation of aegirine). Fluorite is a common constituent in the altered rocks. The pegmatitic syenite frequently contains galena, pyrite and haematite. Pyritiferous zones occur especially in the uppermost part of the sequence.

All the altered syenite is radioactive and the radioactivity seems to increase in proportion to the intensity of alteration. The radioactivity comes, at least in part, from a dark red dense unidentified mineral. The boundary between the altered syenite and fresh nepheline syenite is quite sharp but an intrusive relationship could not be observed. It is possible that this boundary is merely the limit of alteration. Viewed from a distance the syenite displays a subhorizontal pattern of darker and lighter layers. They seem to indicate some large-scale subhorizontal structural or petrological feature which may, therefore, control the distribution of the radioactive altered syenite. It is thought that this mineralisation is derived from late magmatic volatiles rich in thorium, uranium, fluorine, and rare earth elements.

\section{Narssaq-Narssarssuaq district}

The area centred on Narssaq and Narssarssuaq (fig. 18) is defined by the high content of uranium both in stream-sediment and in stream-water samples. The bedrock is composed mostly of 'late' members of the Proterozoic Julianehaab granite in the northern parts and gneiss and syn-orogenic 'early' Julianehåb granite in the southern parts (Vatnaverfi area) which are intruded by the Gardar alkaline complexes and dykes.

From the study of aerial and satellite photographs and the available gravimetric data (Blundell, 1978) this area appears from the high density of lineaments to be a strongly fractured area which surrounds the high gravimetric anomaly centred on the Ilímaussaq alkaline complex in a sub-circular zone of about $50 \mathrm{~km}$ radius.

Following last year's discovery of a boulder containing pitchblende, it was expected that uranium mineralised fractures might explain the geochemical anomalies in this district. The 1980 field season was devoted, therefore, to following up likely structures in as many different parts of the area as possible to determine if a full scale exploration follow-up programme would be justified and to aid in its planning.

The lineaments seen from the aerial photographs can usually be identified in the field as dykes, faults and fractures, or combinations of them. The close association of the dykes with 
the fractures suggests that they were probably penecontemporaneous. These structures are mostly vertical or steeply dipping, but more gently dipping ( $\mathrm{NE} 45^{\circ}$ ) fractures have been mapped in the north-east. Although a NE-SW strike is one of the most important directions, structures occur in many other directions. A WNW-striking lineament in the north of the area proved to be a sedimentary clastic 'dyke' containing fragments of the Eriksfjord Formation. The relative ages and offsets of the various fractures, faults and dykes will only be determined after more rigorous studies; but even at the scale of satellite imagery $(1: 500000)$ there is a distinct impression of an old set of curved lineaments which centre on the Ilímaussaq alkaline complex. These do not appear to dissect the Eriksfjord Formation and their very discontinuity suggests that they are displaced by the other, therefore younger, structures.

The faults and fractures vary in width from micro-fractures to zones up to hundreds of metres across. They are almost invariably associated with a red alteration of the wall rocks. Typically this is seen as initial darkening of the feldspars followed by the disappearance of quartz. This is believed to be the result of fenitisation along the fractures which must have formed feeders for alkaline volatiles presumably related to the Gardar events.

Numerous radioactive occurrences in faults, fractures and alkaline dykes were found. The radioactive dykes found in the vicinity of the Ilímaussaq complex and the Igdlerfigssalik centre of the Igaliko nepheline syenite complex, discussed by Steenfelt \& Tukiainen (this report) are most probably due to thorium enrichment and are similar to those described by Hansen (1968). The occurrences in faults and fractures are always associated with disseminated iron oxides (goethite and specular haematite). Calcite and quartz are common gangue minerals, although the calcite is often leached and white vein quartz tends to be barren of any mineralisation. Dark crystalline quartz, on the other hand, is usually found with the pitchblende and radioactive occurrences. Disseminated sulphides are usually present in variable amounts and include mostly pyrite with some chalcopyrite and occasionally galena. Fluorite is a common constituent in the northern part of the area but is never seen in the Vatnaverfi area to the south.

Pitchblende has now been found at six locations (fig. 18). Four of these are boulders which are thought to come from local structures. One is a small lens measuring about $10 \mathrm{~cm}$ wide and about one metre long in the Igaliko peninsula in a NE-striking minor fracture associated with a major NNE-striking fault. The second occurs in the Vatnaverfi area as joint fillings associated with an ENE fracture zone.

In the north of the area west of Narssarssuaq, NW-SE striking fractures become more prominent and contain most of the radioactive occurrences, although they can also be found in NE-SW trending fractures. The direction of the structures, however, is probably not an important control of the uranium mineralisation, only their presence acts as feeders or traps. Similarly the type of granite does not seem to exert any control over the mineralisation, although it often has marked local and regional variations in radioactive background.

The association of this uranium mineralisation with veins of sulphides, carbonate and quartz indicates a hydrothermal genesis which was probably related to Gardar events. It must be noted, however, that the present land surface is close to the original Proterozoic erosion surface, as shown by the remnants of the Eriksfjord Formation and the occasional sedimentary clastic dykes. It, therefore, seems plausible to suggest that there has been uranium mineralisation related to the Proterozoic unconformity before it was remobilised 
and redistributed by the later hydrothermal activity. Older uraniferous metasediments, of which the rocks in the Tasermiut area are a remnant, could have been a source for this uranium.

\section{Conclusions}

The reconnaissance work in the Motzfeldt centre has demonstrated that there are areas of at least $1 \mathrm{~km}^{2}$ with continuously high radioactivity which seem to be related to subhorizontal structural or petrological features of some tens of metres in thickness. If the uranium content of these radioactive zones are sufficiently high, then potential ore tonnages could prove to be substantial. Detailed geological and radiometrical mapping of the centre, in order to delineate uraniferous zones would seem to be fully justified on economic and purely scientific grounds as the geology is only poorly understood.

The reconnaissance exploration has proved that uranium mineralisation is widely distributed in the Narssaq-Narssarssuaq district. It is, no doubt, responsible for the high uranium values in the exploration geochemical samples. Although the size of the pitchblende occurrences which have been found so far are small, the high grade of the mineralisation, the great frequency of the fracturing and the evidence for an all pervasive mineralising event over a wide area indicate that there is a good possibility of finding economic mineralisation within the Narssaq-Narssarssuaq area. The area as a whole may, perhaps, be termed a 'uranium mineral district'. As the potential targets are small, only detailed follow-up exploration will establish this. At the same time more detailed work on individual showings, and geological mapping to demonstrate the relative ages of the various petrological and mineralising events, will establish the possible origin of this uranium mineralisation.

\section{References}

Allaart, J. H. 1976: Ketilidian mobile belt in South Greenland. In Escher, A. \& Watt, W. S. (edit.) Geology of Greenland, 121-151, Copenhagen: Geol. Surv. Greenland.

Armour-Brown, A., Tukiainen, T. \& Wallin, B. 1980: The South Greenland uranium exploration project. Rapp. Grønlands geol. Unders. 100, 83-86.

Blundell, D. J. 1978: A gravity survey across the Gardar Igneous Province, S. W. Greenland. J. geol. Soc. Lond. 135, 545-554.

Emeleus, C. H. \& Harry, W. T. 1970: The Igaliko nepheline syenite complex. General Description. Bull. Grønlands geol. Unders. 85 (also Meddr Grønland 186,3) $116 \mathrm{pp}$.

Hansen, J. 1968: A study of radioactive veins containing rare earth minerals in the area surrounding the Ilimaussaq alkaline intrusion in South Greenland. Bull. Grønlands geol. Unders. 76 (also Meddr Grenland 181,8) $47 \mathrm{pp}$.

Nielsen, B. L. \& Tukiainen, T. 1981: Uranium-bearing metasediment and granite in the Tasermiut area, South Greenland. Rapp. Grønlands geol. Unders. 105 (this volume).

Steenfelt, A. \& Tukiainen, T. 1981: Uranium-thorium mineralisation in the vicinity of the Igdlerfigssalik centre of the Igaliko nepheline syenite complex, South Greenland. Rapp. Gronlands geol. Unders. 105 (this volume). 